\title{
Gene Expressions Analysis of Seed Physiological Quality in Soybean Cultivars
}

\author{
Alexana Baldoni ${ }^{1}$, Edila Vilella de Resende Von Pinho ${ }^{2}$, Heloisa Oliveira dos Santos ${ }^{2}$, \\ Thais Lima Marques ${ }^{2} \&$ Rucyan Walace Pereira ${ }^{2}$ \\ ${ }^{1}$ Centro Universitário de Patos de Minas, Patos de Minas, MG, Brazil \\ ${ }^{2}$ Departamento de Agricultura, Universidade Federal de Lavras, Lavras, MG, Brazil \\ Correspondence: Heloisa Oliveira dos Santos, Departamento de Agricultura, Universidade Federal de Lavras, \\ Lavras, MG, Brazil. Tel: 55-35-3829-1002. E-mail: heloisa.ufs@gmail.com
}

Received: August 1, 2018

doi:10.5539/jas.v11n2p408

\author{
Accepted: November 6, $2018 \quad$ Online Published: January 15, 2019 \\ URL: https://doi.org/10.5539/jas.v11n2p408
}

\begin{abstract}
Soybean seed production with high physiological quality is important for ensuring populations of recommended plants for each cultivar. It is also known that there is genetic variability for this characteristic among the soybean cultivars. The objective was to study the genes expressionof protein and gene transcript involved in the physiological quality of soybean seeds. The seeds of CD 206 and CD 201 cultivars were classified as high quality while Savana and Emgopa 316 cultivars were classified as low quality by germination and vigor tests. Physiological, enzymatic and transcripts analysis were held in seeds of each cultivar during two harvest seasons, R8 and R8 + 15 days; at protein level the alcohol dehydrogenase isoenzyme systems (ADH), phosphoglucoisomerase (PGI), superoxide dismutase (SOD), catalase (CAT), malate dehydrogenase (MDH) and isocitrate lyase (ICL). The PCR technique in real time (qRT-PCR) was used for transcritome studies for quantitative gene expression analysis. The method used was the comparative $\mathrm{Ct}$ considering the relative expression levels in relation to cultivar of high quality CD 201. It is concluded that there is higher enzymes expression involved in respiration, alcohol dehydrogenase (ADH), malate dehydrogenase (MDH) and phosphoglucoisomerase (PGI), in seeds with high physiological quality, especially when harvesting is delayed. The proteomic and transcriptomic profiles related to the genes involved in free radicals removing systems in soybeans varies among cultivars and the season of seed harvest.
\end{abstract}

Keywords: isoenzymes genes, physological quality, seeds, soybean

\section{Introduction}

In Brazil, the improvement of seed and grain characteristics of agronomic and industrial use soybean cultivars is gaining importance in recent years. It has been observed genetic diversity for physiological quality among soybean cultivars which could be helpful to investigate lines with better seed physiological traits for Brazilian weather conditions. After physiological maturity of seeds, the high temperature and relative humidity can accelerate the deterioration process, which can cause reduction in physiological quality of seeds (França-Neto et al., 2010).

Therefore, in breeding programs, technologies has been increasingly sought to enhance the selection of soybean cultivars with high seed quality. Germination and vigor tests were useful for testing seed quality (Gris et al., 2010; Menezes et al., 2009).

According to Braccini et al. (2000), there is considerable variation in tolerance to harvesting delays among the soybean cultivars- There was high correlation between the reduced germination by delays in seed harvest and increase in the incidence of infected seeds by fungi and bacteria. Thus, harvest delay causes seed deterioration with significant effects on seeds quality.

Enzymes of seed respiratory process, such as alcohol dehydrogenase (ADH), malate dehydrogenase (MDH) and phosphoglucoisomerase (PGI), and as antioxidents such as superoxide dismutase (SOD) and catalase (CAT) and enzymes involved in degradation of reserve materials, such as isocitrate lyase (ICL), were the key seed deteriorating factors (Taiz \& Zeiger, 2004; Buchanan, Gruissem, \& Jones, 2005; Lehninger, 2006). 
The transcriptomic and proteomic techniques allow improving cultivars with high quality seeds. Differential gene expression by qualitative and quantitative determination of the transcripts related to seed physiological quality, identification of differentially expressed genes and their metabolic functions were investigated (Kuhn et al., 2001).

There were molecular studies related to drought tolerance involving gene expression in soybean, (Polizel et al., 2011; Stolf-Moreira et al., 2010). However, studies involving gene expression related to the soybean seeds quality are still sparse in the literature.

Thus, studies on the enzymes expression in soybean seeds associated with seed physiological quality and the cultivar selection stage with high physiological quality are important in seeds quality control programs. The objective of the researche study was to understand the gene expression of soybean seeds harvested at different seasons by evaluating the protein and transcripts by PCR technique in real time.

\section{Material and Methods}

The study was conducted at the experimental area and in the Laboratory Center of Seed Analysis, Agriculture Department, Federal University of Lavras. Lavras city is in southern Minas Gerais state that, according to Köppen classification presents climate Cwa (Ometo, 1981). It is situated at an altitude $918 \mathrm{~m}$, at $21^{\circ} 14$ south latitude and $45^{\circ} 00$ west longitude.

Seeds of Savana, Engopa 316, Conquista, MS 8400, CD 201, CD 206, CD 202 and CD 215 cultivars were produced in an area with soil classified as Latosol dystrophic, carrying out seeding in conventional system.

Soil analysis sowing, fertilization were done according to the recommendations of Ribeiro, Guimarães and Vicente (1999). Fungicide Vitavax Thiram $200 \mathrm{SC}$ was used for seed treatment at a dosage of $250 \mathrm{ml} / 100 \mathrm{~kg}$ of seeds. Then, the seeds were inoculated with commercial product turfy, aiming to ensure a minimum population of 1200000 bacteria/seed.

The seed multiplication was carried out in a randomized block design with three replications in December 2010. The experimental units consists of 4 lines ( $5 \mathrm{~m}$ each), considering only the 2 central lines as useful area. Thinning was conducted maintaining a population of 16 plants per linear meter.

Manual harvesting was performed when the plants were in the phenological stages according to Fehr and Caviness (1977). Drying was carried out in the shade until the seeds reached $13 \%$ water content.

The seeds retained in a circular sieve between $5.55 \mathrm{~mm}$ and $6.35 \mathrm{~mm}$ were used as a standardized seeds' size to later carry out experimental evaluations.

For germination and accelerated aging tests, the seeds were treated with fungicide Vitavax Thiram 200SC at a dose $250 \mathrm{ml} / \mathrm{kg}$ of seeds. 300 seeds per cultivar were used for both tests. In germination tests, the seeds were sown on paper type Germitest moistened with distilled water at a ratio of 2.5 times the weight of the paper, aiming adequately moistened and uniformity of test conditions. The seeds remain in the germination chamber which was set to $251{ }^{\circ} \mathrm{C}$. Evaluations were done at five days (first count) and eight days (final count) after sowing, computing the normal seedlings percentage, according to the criteria set by the Rules for Seed Analysis (Brazil, 2009).

For the accelerated aging test, the method used was the mini-chambers type "gerbox", wherein $42 \mathrm{~g}$ seeds were distributed over a dropdown screen inside the box containing $40 \mathrm{ml}$ of water and exposed to a temperature of $42^{\circ} \mathrm{C}$ for 72 hours. Then, the germination test was performed according to Vieira and Carvalho (1994), with 6 repetitions of 50 seeds per each cultivar.

The electrical conductivity (EC) test were done for four replicates of 50 intact seeds per each cultivar and were weighed. After that, they were placed in plastic glasses of $200 \mathrm{ml}$ capacity containing $75 \mathrm{ml}$ of deionized water for 24 hours at $25{ }^{\circ} \mathrm{C}$ temperature. By means of conductivity, meter brand DIGIMED, CD 21A Model, conductivity reading of imbibition solution for the seeds of each cultivar and the results were expressed as $\mathrm{S} / \mathrm{cm} / \mathrm{g}$ seeds (Vieira; Carvalho, 1994).

Statistical analysis was performed using the Sisvar program (Ferreira, 2003) and the data were interpreted by variance analysis in factorial $8 \times 2,8$ cultivars and two harvest seasons (stages R8 and R8 +15 days). Scott-Knott test was used to compare averages

After harvest, some seeds were immediately packaged in liquid nitrogen and stored at $-80{ }^{\circ} \mathrm{C}$ for subsequent genes expression analysis of seed physiological quality. PCR technique in real time (qPCR) was used for transcripts analysis and the electrophoresis technique was employed for protein analysis.

The seeds were ground liquid nitrogen with addition of the reagent Pure Link RNA Plant ${ }^{\circledR}$ (Invitrogen), following the manufacturer's specifications for the RNA isolation. 
The RNA integrity and purity were assessed during all stages by electrophoresis in a denaturing agarose gel (stained with SYBR ${ }^{\circledR}$ Green II, Applied Biosystems) and in spectrophotometer (NanoVue).

After nucleic acids extraction, the RNA samples were treated with DNAse free solution to avoid any contamination with DNA. For this, Kit DNAse Turbo Free ${ }^{\circledR}$ AMBIOM was used following the manufacturer's recommended protocol.

After the extraction and purification process, the mRNA was used as a template for cDNA synthesis. High Capacity cDNA Reverse Transcription cDNA $^{\circledR}$ da kit from Applied Biosystems, was used and followed the manufacturer's recommended protocol. The cDNA efficiency and synthesis was confirmed by conventional PCR.

The sequences of the target genes related to seed physiological quality were obtained by searching the database of the genome maize in GenBank. Based on these sequences primers were designed using the Primer Express 3.0 software (Applied Biosystems). The primers sequences are presented in Table 1. The GAPDH and CYP2 genes were selected as endogenous controls because they had constitutive expression in all treatments.

Table 1. Primers used in qRT-PCR analysis

\begin{tabular}{ll}
\hline Gene & Primer Sequence \\
\hline GAPDH F & 5' TCCAAGGGGACCTAACGGAGA 3' \\
GAPDH R & 5' TGGGTCAAGAGCTGGATGGTG 3' \\
CYP2 F & 5' CGGGACCAGTGTGCTTCTTCA 3' \\
CYP2 R & 5' CCCCTCCACTACAAAGGCTCG 3' \\
SOD F & 5' GTTGAAAAGCCA GGGGACA 3' \\
SOD R & 5' TCTTACCCCTTGA GCGTGG 3' \\
ADH F & 5' TCCTGACTATTATTTCCGCATCAC 3' \\
ADH R & 5' TTATCACACATGCGCTTGAATTT 3' \\
CAT F & 5' TGTTGCTGCAGTTGCGTACA 3' \\
CAT R & 5' CGGAAAACCAAGTCTCATCAACTA 3' \\
PGI F & 5' AACAACGGCACTGACAGTTACG 3' \\
PGI R & 5' GAGCACCACCCTGTTTGGTT 3' \\
MDH F & 5' GGCACCCTGTTTGGTGGGACA 3' \\
MDH R & 5' GTTGAAAAGCCA GGGGACA 3' \\
ICL F & 5' TGGGTCAAGAGCTGGATGGTG 3' \\
ICL R & 5' CGGGACCAGTGTGCTTCTTCA 3' \\
\hline
\end{tabular}

Note. (F) Primer forward sequence. (R) Primer reverse sequence.

For PCR analysis in real time, the real-time apparatus PCR system 7500 (Applied Biosystems) was used to quantify the gene expression. The qRT-PCR was carried out using SYBR ${ }^{\circledR}$ Green PCR Master Mix (Applied Biosystems) and cDNA synthesized from the extracted RNA. The thermal conditions for PCR were $50{ }^{\circ} \mathrm{C}$ for 2 min, $95^{\circ} \mathrm{C}$ for $10 \mathrm{~min}, 45$ cycles of $95{ }^{\circ} \mathrm{C}$ for $2 \mathrm{~min}, 62^{\circ} \mathrm{C}$ for $30 \mathrm{~s}$ and $72{ }^{\circ} \mathrm{C}$ for $30 \mathrm{~s}$. Data were collected and stored in the program 7500 Fast Software (Version 2.1). For each reaction $10 \mu \mathrm{L}$ of SYBR Green PCR Master Mix (Applied Biosystems), $2 \mu \mathrm{L}$ of cDNA ( $250 \mathrm{ng}$ ), $0.4 \mu \mathrm{L}$ of forward and reverse primers and $7.2 \mu \mathrm{L}$ of autoclaved ultrapure water to make up the final volume of $20.0 \mu \mathrm{L} /$ sample. Negative controls, composed of water and endogenous controls, were included in every analysis. All reactions were performed in triplicates.

Data was generated automatically from software v.2.0.1 of the 7500 qPCR system in real time (Applied Biosystems). The comparative Ct method of relative quantification, where Ct's (Threshold Cycle) of the samples were normalized using the Ct's endogenous control. For that, previously conducted a validation experiment in order to verify that the amplification efficiencies of target genes and endogenous controls are similar and close to $100 \%$. Standard curves for the efficiency test for the target genes were generated from the following dilutions: 1:5, $1: 25,1: 125,1: 625$ and 1:3125. This procedure also allowed the definition of the best dilution cDNA to be used in each reaction, which was 1:5.

For the enzymes analysis, two repetitions of 50 seeds from each treatment were grinded in mortar containing liquid nitrogen and antioxidant PVP (Polyvinyl Pyrrolidone). For the isoenzymes analysis ICL and MDH, plant material extraction was carried out at 2 days after sowing (during the germination process). Subsamples were taken from 
$100 \mathrm{mg}$ to which $300 \mu \mathrm{l}$ of ethylether $+300 \mu \mathrm{l}$ of water were added to remove the oil. The samples were centrifuged for 20 minutes at $14000 \mathrm{rpm}$ at $4{ }^{\circ} \mathrm{C}$, performing the process twice. For the enzymes extraction, $250 \mu 1$ of extraction buffer (Tris $\mathrm{HCl} 0.2 \mathrm{M} \mathrm{pH} 8+0.1 \%$ beta mercaptoethanol) was used. Then, the samples were shaken rapidly in beater staying overnight in the refrigerator. Next morning the samples were centrifuged at $4{ }^{\circ} \mathrm{C}$ at 14000 rpm for 30 minutes. $50 \mu \mathrm{L}$ of supernatant was used to run gel. The gel buffer/electrode system used was Trisglicina $\mathrm{pH}$ 8.9. The gel was ran at $150 \mathrm{~V}$ for 5 hours. After electrophoresis, it was proceeded the revelation of the enzymes superoxide dismutase (SOD), alcohol dehydrogenase (ADH), catalase (CAT) and phosphoglucoisomerase (PGI), malate dehydrogenase (MDH) and isocitrate lyase (ICL) (Santos et al., 2016).

\section{Results}

Analysis of variance of data from germination and vigor tests revealed significant differences to the seed physiological quality among cultivars and harvest seasons.

The results observed in germination, electrical conductivity and accelerated aging experiments presented cultivars with difference when seeds harvested 15 days after R8 stage (Table 2).

From EC tests, differences in vigor of cultivars was observed when harvested at R8 stage.

For the accelerated aging test there was no difference in seed vigor among the cultivars, when the harvest was conducted at the R8 stage. However, when the harvest was conducted 15 days after the R8 stage, lower vigor values were observed in seeds of the Conquista, Savana, Engopa 316, MS 8400 and CD 215 cultivars.

Table 2. Average germination, accelerated aging and electrical conductivity of soybean seeds

\begin{tabular}{|c|c|c|c|c|c|c|}
\hline \multirow{2}{*}{$\begin{array}{l}\text { Tests } \\
\text { Stage }\end{array}$} & \multicolumn{2}{|c|}{ Germination } & \multicolumn{2}{|c|}{ Accelerated aging } & \multicolumn{2}{|c|}{ Electrical conductivity } \\
\hline & R8 & $\mathbf{R 8 +}$ & $\mathbf{R 8}$ & R8 + & $\mathbf{R 8}$ & $\mathbf{R 8 +}$ \\
\hline \multicolumn{7}{|l|}{ Cultivars } \\
\hline CD 206 & $86 \mathrm{~A} \mathrm{a}$ & $83 \mathrm{~A} \mathrm{a}$ & $82 \mathrm{~A} \mathrm{a}$ & $66 \mathrm{~A} \mathrm{~b}$ & $54.16 \mathrm{~A} \mathrm{a}$ & $72.41 \mathrm{~A} \mathrm{~b}$ \\
\hline CD 201 & $86 \mathrm{~A} \mathrm{a}$ & $84 \mathrm{~A} \mathrm{a}$ & $76 \mathrm{~A} \mathrm{a}$ & $66 \mathrm{~A} \mathrm{a}$ & $75.66 \mathrm{~B} \mathrm{a}$ & $85.75 \mathrm{~B} \mathrm{~b}$ \\
\hline MS 8400 & $87 \mathrm{~A} \mathrm{a}$ & $76 \mathrm{~B} \mathrm{~b}$ & $83 \mathrm{~A} \mathrm{a}$ & $68 \mathrm{~A} \mathrm{~b}$ & $80.58 \mathrm{~A} \mathrm{a}$ & $88.08 \mathrm{~B} \mathrm{a}$ \\
\hline CONQUISTA & $90 \mathrm{~A} \mathrm{a}$ & $70 \mathrm{C} \mathrm{b}$ & $78 \mathrm{~A} \mathrm{a}$ & $52 \mathrm{~B} \mathrm{~b}$ & $74.25 \mathrm{~B} \mathrm{a}$ & $90.58 \mathrm{~B} \mathrm{~b}$ \\
\hline CD 202 & $84 \mathrm{~A} \mathrm{a}$ & $86 \mathrm{~A} \mathrm{a}$ & $72 \mathrm{~A} \mathrm{a}$ & $73 \mathrm{~A} \mathrm{a}$ & $74.58 \mathrm{~B} \mathrm{a}$ & $78.08 \mathrm{~A} \mathrm{a}$ \\
\hline SAVANA & $88 \mathrm{~A} \mathrm{a}$ & $68 \mathrm{C} \mathrm{b}$ & $68 \mathrm{~A} \mathrm{a}$ & $44 \mathrm{~B} \mathrm{~b}$ & $87.75 \mathrm{C} \mathrm{a}$ & $108.08 \mathrm{C} \mathrm{b}$ \\
\hline ENGOPA 316 & $88 \mathrm{~A} \mathrm{a}$ & $67 \mathrm{C} \mathrm{b}$ & $80 \mathrm{~A} \mathrm{a}$ & $27 \mathrm{C} \mathrm{b}$ & $69.66 \mathrm{~B} \mathrm{a}$ & $110.66 \mathrm{C} \mathrm{b}$ \\
\hline CD 215 & $87 \mathrm{~A} \mathrm{a}$ & $76 \mathrm{~B} \mathrm{~b}$ & $68 \mathrm{~A} \mathrm{a}$ & $51 \mathrm{~B} \mathrm{~b}$ & $78.91 \mathrm{~A} \mathrm{a}$ & $94.83 \mathrm{~B} \mathrm{~b}$ \\
\hline $\mathrm{CV} \%$ & 8.05 & & 17.68 & & 12.6 & \\
\hline
\end{tabular}

Note. Average followed by the same lowercase letter on the line and the same capital letter in the column do not differ by the Scott-Knott test at 5\% significance.

The highest enzymes activity for the enzyme ADH was observed in seeds of CD 201 and CD 206 cultivars. These cultivars were classified for high physiological quality in both harvest seasons, with higher expression of the enzyme in seeds of the CD 206 cultivar (Figure 1).

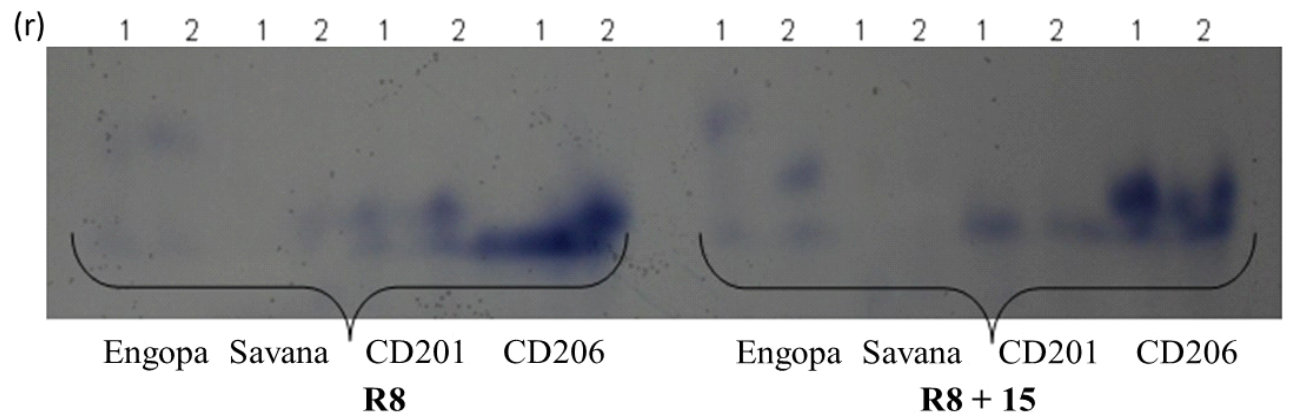

Figure 1. Isoenzymatic patterns of high soybean seeds (CD 201 and CD 206) and low physiological quality (Engopa 316 and Savana), during harvest seasons R8 and R8 + 15 days, revealed to the ADH enzyme. (r: repetition) 
The PGI enzyme activity was presented in Figure 2. This enzyme expression was higher in high quality seeds and harvested 15 days after R8 stage.

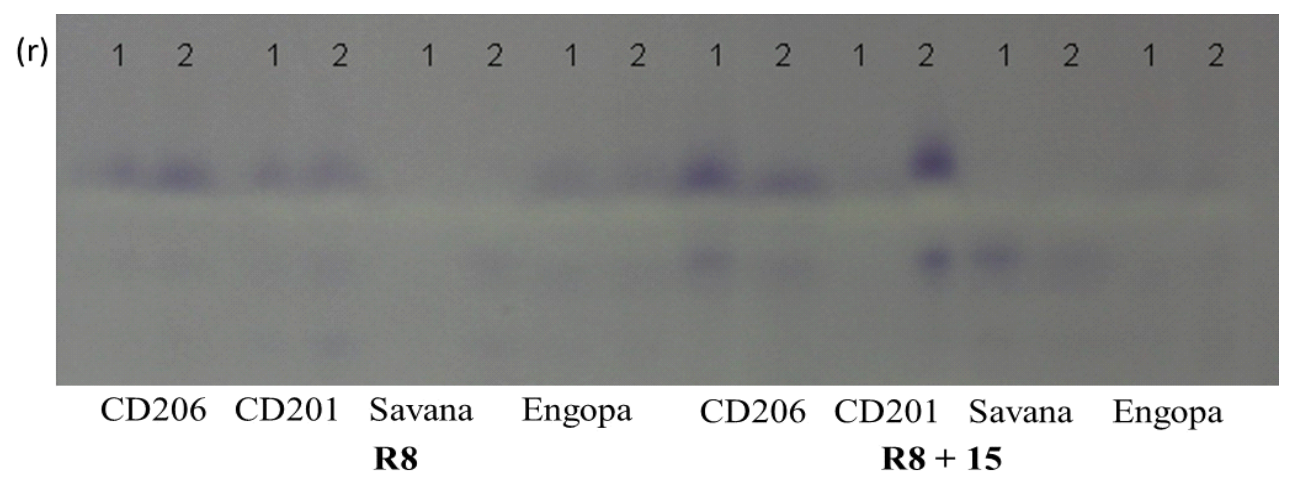

Figure 2. Isoenzymatic patterns of high soybean seeds (CD 201 and CD 206) and low physiological quality (Engopa 316 and Savana), during harvest seasons R8 and R8 + 15 days, revealed to the PGI enzyme. (r: repetition)

An increased activity of SOD enzyme was observed in seeds harvested at the R8 stage. The cultivars Savana and Engopa 316 were classified with low seed quality (Figure 3).

There was a change in SOD enzyme pattern of seeds harvested at 15 days after R8 stage in all the cultivars.

In CD 201, CD 206 and Engopa 316 cultivars, seeds harvested at R8 stage +15 days, there was a higher expression of some isoforms that were also expressed in seeds harvested at the R8 stage. The observed isoforms were numbered in Figure 3 as 1, 2, 3 and 4. In Savana and Engopa 316 cultivars, seeds classified with low physiological quality there was lower expression of some isoforms of SOD enzyme, such as the numbered 5 and 6 . There was significant reduction in seed physiological quality of these cultivars evaluated by the germination and vigor test, when the harvest was delayed 15 days after R8 stage.

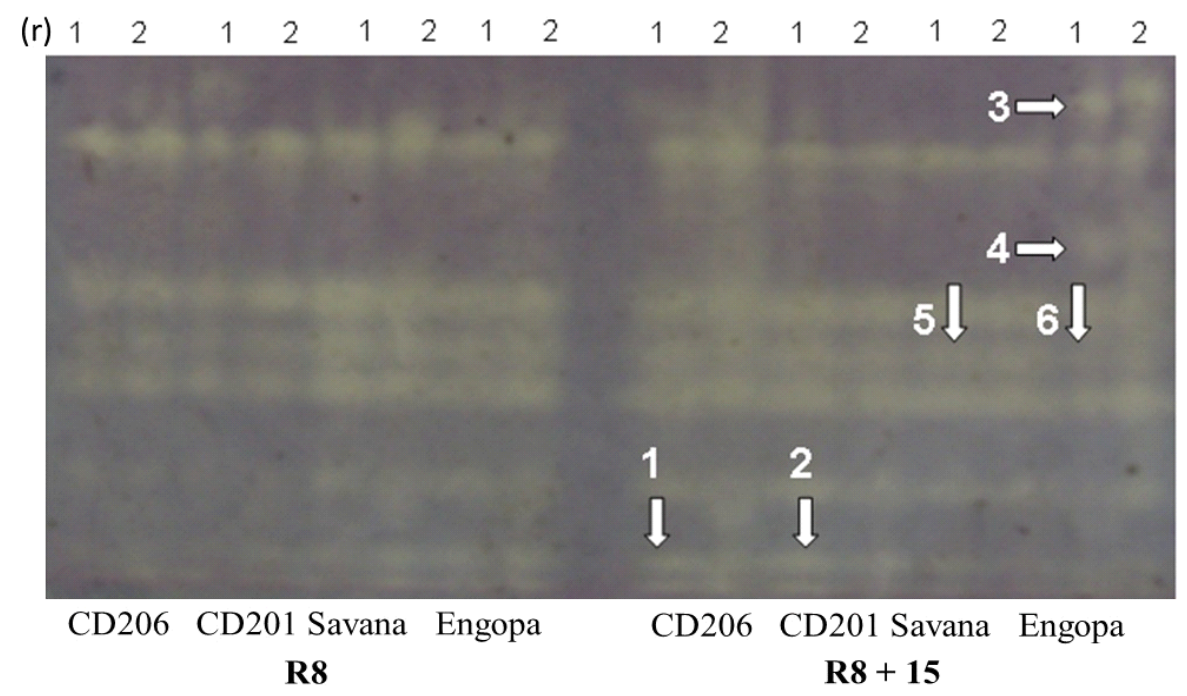

Figure 3. Isoenzymatic patterns of high soybean seeds (CD 201 and CD 206) and low physiological quality (Engopa 316 and Savana), during harvest seasons R8 and R8 + 15 days, revealed to the SOD enzyme. (r: repetition)

Another enzyme involved in the removal of hydrogen peroxide formed from the SOD activity is catalase (CAT). In this study, no significant difference was observed in the enzyme expression among treatments and within each harvest season. However, comparing the two harvest seasons, the expression of this enzyme was higher in seeds harvested at the R8 stage (Figure 4). 


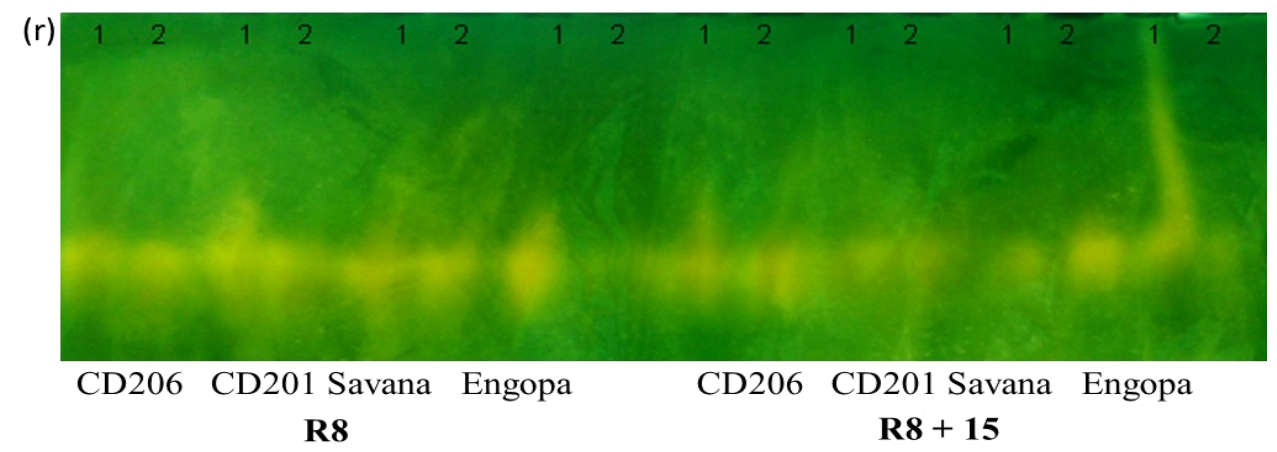

Figure 4. Isoenzymatic patterns of high soybean seeds (CD 201 and CD 206) and low physiological quality (Engopa 316 and Savana), during harvest seasons R8 and R8 +15 days, revealed to the CAT enzyme. (r: repetition)

The MDH enzyme (Figure 5) activity was reduced in seeds harvested 15 days after the R8 stage of the cultivars CD 206, CD 201 and Savana. There was no activity of this enzyme in the seeds of Engopa 316 cultivar in the two harvest seasons. The seed with low physiological quality is expected with a lower respiratory activity.

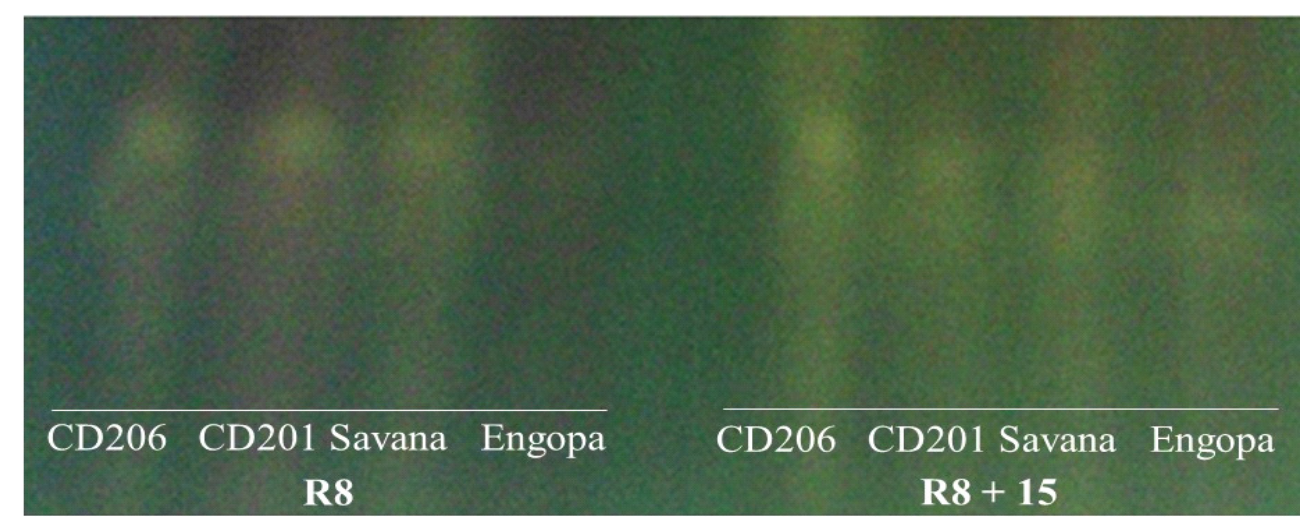

Figure 5. Isoenzymatic patterns of high soybean seeds (CD 201 and CD 206) and low physiological quality (Engopa 316 and Savana), during harvest seasons R8 and R8 + 15 days, revealed to the MDH enzyme

It was observed a lower expression of ICL enzyme in seeds harvested at the R8 stage in comparison to those harvested 15 days after R8 stage (Figure 6). However, in seeds of the Engopa 316 cultivar, reduction in activity of ICL enzyme was observed due to harvest delay.

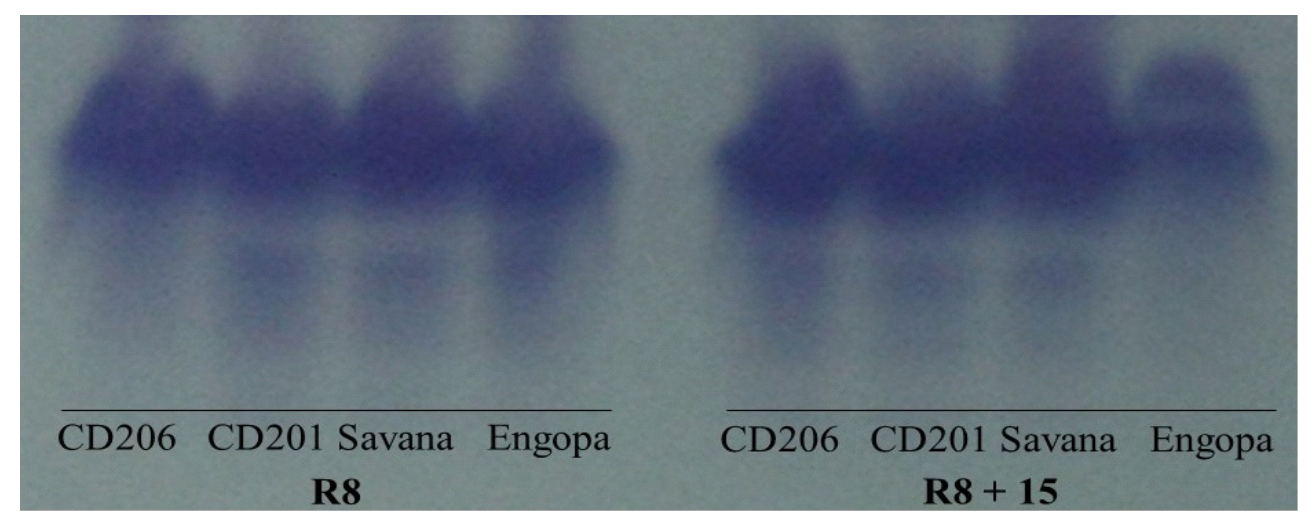

Figure 6. Isoenzymatic patterns of high soybean seeds (CD 201 and CD 206) and low physiological quality (Engopa 316 and Savana), during harvest seasons R8 and R8 + 15 days, revealed to the ICL enzyme 
The gene expression studies of transcripts by RTq-PCR technique, revealed the expression with high physiological quality seeds in CD 201 cultivar. In Figure 7, the expression of alcohol dehydrogenase gene (ADH), superoxide dismutase (SOD), catalase (CAT) and phosphoglucoisomerase (PGI) in seeds of low and high quality cultivars during the R8 stage was presented. The SOD gene expression was higher in seeds of Savana and Engopa 316 cultivars, considered low physiological quality. The seeds harvested 15 days after R8 stage (Figure 8), higher expression of this gene was observed in seeds of the CD 206 cultivar and lower expression was observed in seeds of the Engopa 316 cultivar, the latter being classified as low seeds quality.

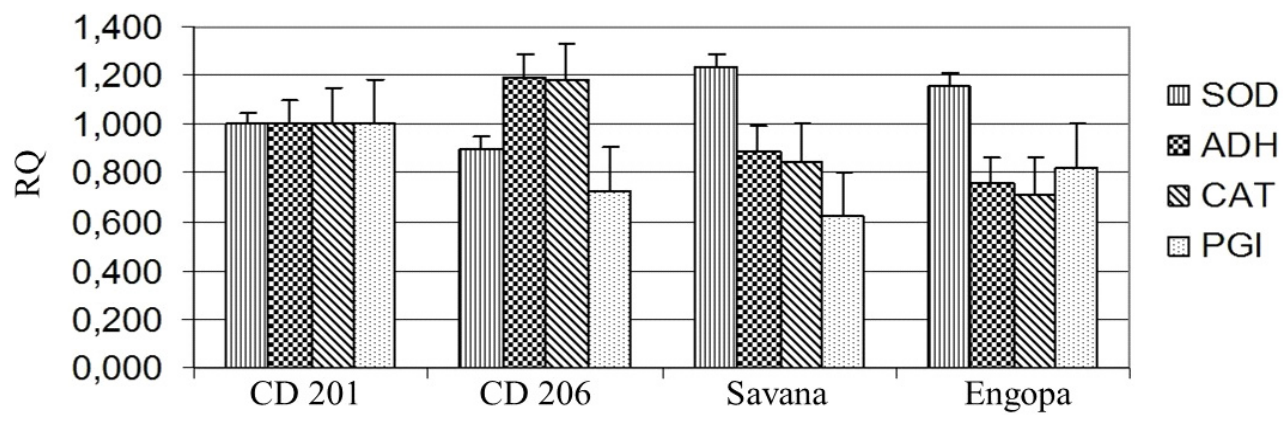

Figure 7. Profile of relative quantitative expression SOD, ADH, CAT and PGI genes, during the development R8 stage, high soybean seeds (CD 201 and CD206) and low physiological quality (Savana and Engopa 316).

Bars referring to standard deviation of triplicates

For CAT gene, it was observed a higher expression in seeds of CD 206 cultivar and lower expression in seeds of Savana and Engopa 316 cultivars, while low quality, when harvested at the R8 stage. When the harvest was delayed 15 days after R8, the expression of this gene was higher in seeds of Savana cultivar, classified as low quality.

Regarding the results of the genes involved in seed respiratory processes, the ADH gene was more expressed in seeds of high quality cultivars, when harvested at the R8 stage. Numerically, higher expression was observed in seeds harvested 15 days after R8 stage. It is noteworthy that the ADH enzyme expression as assessed by electrophoresis technique, was also higher in cultivars with seeds classified as high physiological quality.

When the harvest was delayed (R8 + 15 days), higher ADH gene expression was observed in seeds CD 206 and Engopa 316 cultivars and lower expression in seeds of CD 201 and Savana cultivars. So for this gene, considering harvest delay was not possible to establish a relation between the physiological quality of seeds and the ADH gene expression assessed in this study.

The PGI gene expression was higher in seeds CD 201cultivar, considering the R8 stage and lower in seeds of Savana cultivar, and gene expression in the latter did not differ from that observed in seeds of CD 206 cultivar. This gene expression in seeds of low quality cultivars decreases at harvest season R8 +15 days in relation to those harvested at the R8 stage. For the CD 206 cultivar, seeds harvested 15 days after R8 stage, the expression was higher compared to those observed in seeds from other cultivars. Higher expression of this gene was also observed in CD 201 cultivar, compared to that observed in seeds from Savana and Engopa 316 cultivars. When PGI enzyme expression was evaluated by electrophoresis technique, higher activity of this enzyme was observed, in high quality seeds, also confirming the results observed in germination and vigor tests. 


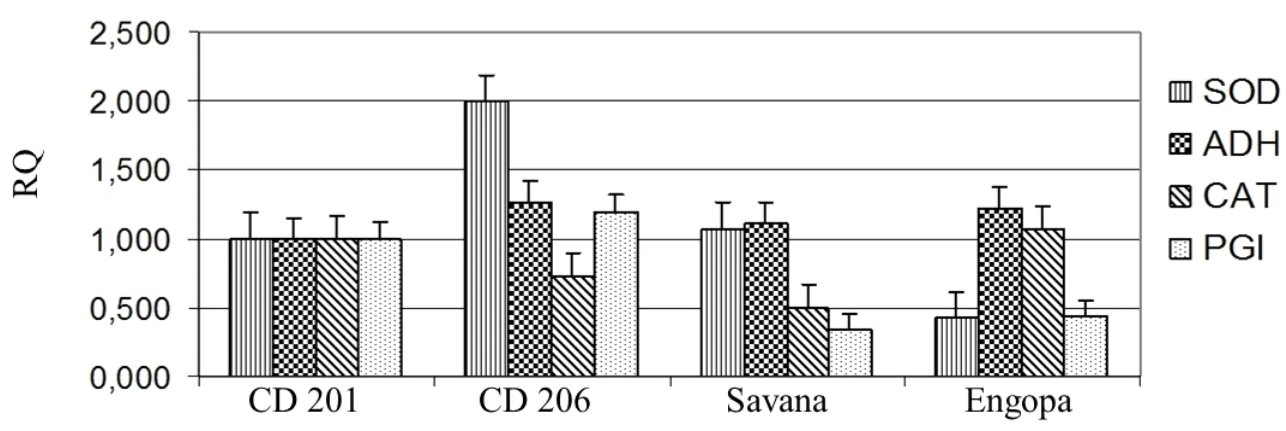

Figure 8. Profile of relative quantitative expression SOD, ADH, CAT and PGI genes, during the harvest season R8 +15 days, high soybean seeds (CD 201 and CD206) and low physiological quality (Savana and Engopa 316).

Bars referring to standard deviation of triplicates

Higher MDH gene expression was observed in seeds of Savana and Engopa 316 cultivars, when the seeds were harvested at the R8 stage (Figure 9). However, when the harvesting was carried out 15 days after R8 stage (Figure 10), the highest gene expression was observed in seeds of CD 201 cultivar. In this harvest condition (R8 + 15 days), there was no difference in MDH gene expression among seeds of CD 206, Savana and Engopa 316 cultivars.

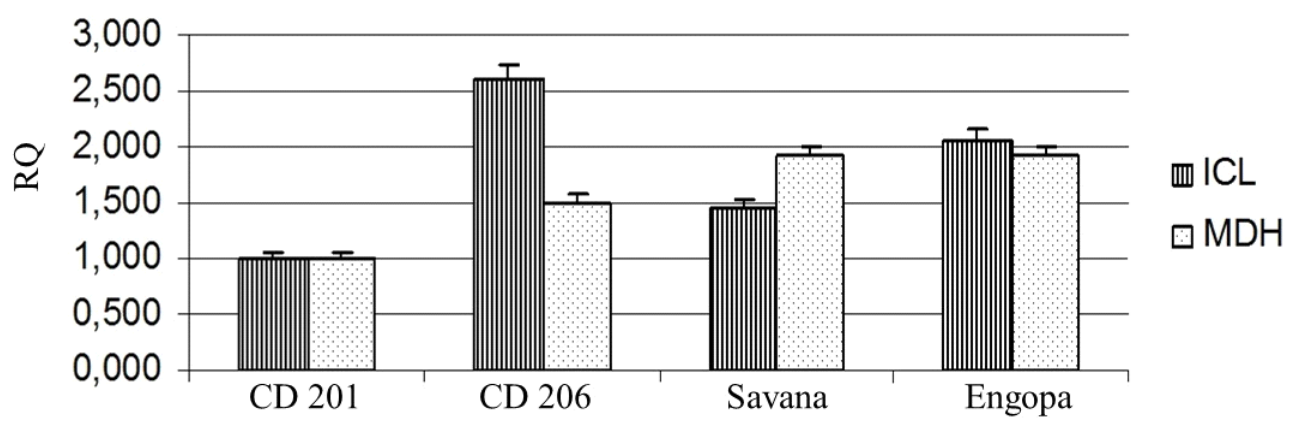

Figure 9. Profile of relative quantitative expression ICL and MDH genes, during the R8 development stage, high soybean seeds (CD 201 and CD206) and low physiological quality (Savana and Engopa 316).

Bars referring to standard deviation of triplicates

The gene expressions of isocitrate lyase enzyme were observed with significant differences among the treatments. Following, in decreasing order, it was observed a higher gene expression in seeds of CD 206, Engopa 316, Savana and CD 201 cultivars, when harvested at R8 stage (Figure 9). However, seeds harvested 15 days after the R8 stage, higher gene expression was observed in seeds of CD 201 cultivar. The gene expression values in seeds of CD 206 and Engopa 316 cultivars did not differ from one another. Lower gene expression value was observed in seeds of Savana cultivar classified as low physiological quality of seeds (Figure 10). 


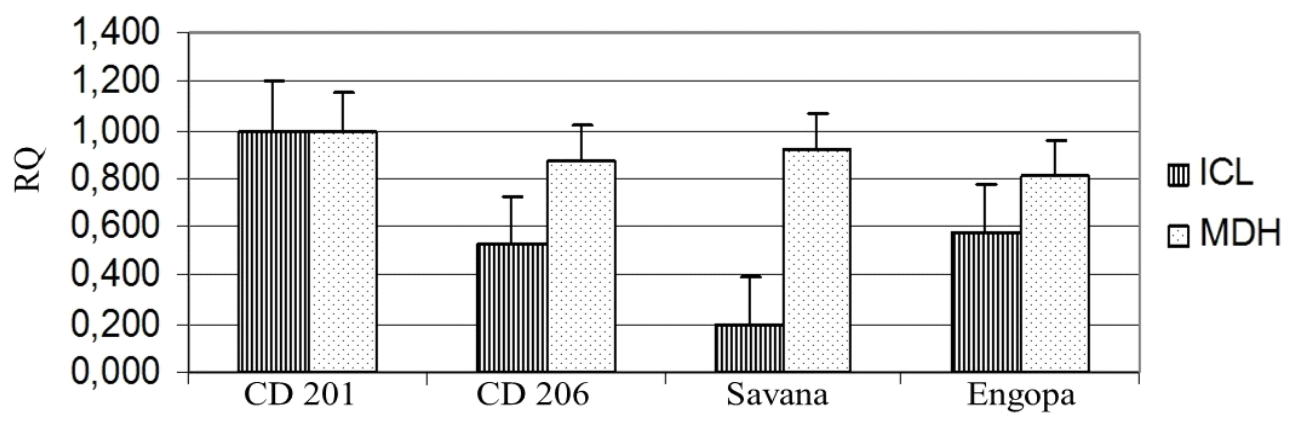

Figure 10. Profile of relative quantitative expression ICL and MDH genes, during the harvest season R $8+15$ days, high soybean seeds (CD 201 and CD206) and low physiological quality (Savana and Engopa 316).

Bars referring to standard deviation of triplicates

\section{Discussion}

The cultivars classification at different levels of physiological quality varied with the harvest season. In CD 206, CD 201 and CD 202 cultivars, seeds harvested at the R8 stage + 15 days were observed with highest germination values. The harvest delay usually affects the seeds quality, because seeds can be exposed to adverse climatic conditions (Gris et al., 2010).

By electrical conductivity test, significant differences were observed in vigor among cultivars and harvesting stages. According to Vieira and Krzyzanowski (1999), the conductivity standard values to be considered should be $70-80 \mathrm{~S} / \mathrm{cm} / \mathrm{g}$, indicating high to médium soybean seeds quality. The electrical conductivity values in seeds harvested at the R8 stage were in the standard reference, except those observed in seeds of Savana cultivar. In seeds harvested at the R8 stage +15 days, considering the standard in reference, only the CD 206 and CD 202 cultivars were classified as high vigor. In absolute terms, the highest conductivity values were observed in seeds of Savana and Engopa 316 cultivars.

It should be noted that the results observed in tests to evaluate the physiological quality of soybean seeds, there was a greater variability among the cultivars when seeds were harvested 15 days after R8 stage. Except for the results observed in the EC test, it was not possible to distinguish the cultivars based on the physiological quality when the harvest was carried out at the R8 stage. Probably this has happened as a result of favorable weather conditions during the maturation process and after physiological maturation of seeds.

By germination test, the accelerated aging and electrical conductivity for CD 202 cultivar, high physiological quality of seeds was observed even with harvest delay of seeds. Lower germination and vigor values were observed in seeds of Engopa 316 and Savana cultivar, especially when there was a harvest delay of seeds. It is emphasized that these results are comparable, since the seeds of the eight cultivars were grown under the same edaphoclimatic conditions. The cultivars Engopa 316 and Savana were considered as low quality and CD 201 and CD 206 cultivars as high quality.

The analysis of the alcohol dehydrogenase enzyme which is related to anaerobic respiration promoting the reduction from acetaldehyde to ethanol (Buchanan, Gruissem, \& Jones, 2005), its expression was more intense in high quality seeds at 15 days after the R8 stage. Probably, the action of this enzyme has been more effective in seeds in this condition, since seeds harvested 15 days after R8 stage was observed with lower physiological quality. The ADH is involved in the breathing process and has the function removing the acetaldehyde in seeds.

At 15 days after R8 stage, the seeds are more vulnerable to deterioration and consequently with higher acetaldehyde production which is considered more toxic to the seeds when compared to ethanol (Zhang \& Kirkham, 1994). Similar pattern to the ADH activity was found by Santos et al. (2015) in pepper seeds with high physiological quality, which was observed with the higher ADH enzyme activity.

PGI works in glycolysis reactions (Lehninger, 2006) and plays a vital role in plants.

The highest enzyme expression in seeds of cultivars with high quality reflects the enzyme effectiveness in the phosphorylation process of sugars in glycolysis, important for energy production, during respiration.

In previous research papers related to seed respiration and the seed respiratory enzymes activities results were presented with higher expression of these enzymes in seeds with high physiological quality. Castro (2011) studied respiration of maize seed through Pettenkofer test and observed higher respiration of seeds with high quality and 
higher expression of MDH enzyme in seeds. By means of stoichiometric calculations, the amount of $\mathrm{CO}_{2}$ released from the seed during respiration can be obtained. As a result of the seeds deterioration process, there is an impairment of the respiratory activity of these enzymes. Thus, seeds with lower physiological quality should present bands with lower intensity.

In addition to the enzymes involved in respiration, those compounds related to the removal of free radicals in seeds are also important as molecular markers for the seeds quality.

SOD is considered as a free radicals removing enzyme and is considered as one of the first to act in defense against reactive oxygen species (ROS). The low seed physiological quality of Savana and Engopa 316 cultivars harvested at the R8 stage, can be associated with higher SOD activity and related to the ROS elimination that were produced in seeds of these cultivars. The hydrogen peroxide formed as a SOD product, although less reactive than acetaldehyde at high concentrations becomes toxic, because they can react forming hydroxyl radicals, causing lipid peroxidation (Bowler, Montagu, \& Inzé, 1992).

In seeds harvested 15 days after R8 stage, low physiological seeds quality was observed in comparison to those harvested at the R8 stage. In deteriorated seeds, lower activity of this enzyme hás been observed with lower efficiency of free radicals removing systems. According to Jeng and Sung (1994), when the seed is aged, there is higher lipid peroxidation and reduction in the free radical removal enzymes activity of peroxides such as CAT.

The MDH enzyme has been associated with the biosynthesis of oxaloacetate (OAA), by interconversion of malate to oxaloacetate during the tricarboxylic acid cycle (Krebs cycle) in plants (Weeden \& Wendel, 1990). Thus, this enzyme takes an important role in a wide variety of biosynthetic reactions, such as amino acid synthesis, gluconeogenesis, maintaining the redox potential and the exchange of metabolites between the cytoplasm and organelles (Lin et al., 2003). However, it is expected that MDH activity is intense in the early stages of germination process in which synthesis of new seed tissues requires more energy for growth.

Martins et al. (2000), while researching the ICL activity in soybean seeds during germination, observed an increase of this enzyme activity. These data corroborate with the highest observed ICL activity during the R8 stage +15 days, when the seeds were extremely subject to deterioration. In seeds harvested at the R8 stage there was more ICL enzyme activity in seeds of CD 206 cultivar. Seeds harvested 15 days after R8 stage, there was lower activity of this enzyme in seeds Engopa 316 cultivar, in comparison to the other, at the same time. Carvalho (2013) observed higher ICL activity in soybean seeds cultivars with better physiological quality. Highly deteriorated seeds have been observed with lower activity of this enzyme with lower efficiency of free radicals removing systems. In soybeans seeds, the isocitrate lyase is considered a key enzyme in the regulation of glyoxylate cycle and is involved in the lipids metabolism stored in oil seeds, and in the development of glyoxysome activities.

The transcript expression data, when compared with those of enzymes expression data evaluated by electrophoresis technique and the results of germination and vigor tests, explain the factors complexity that affect the physiological quality of soybean seeds. According to Carrington and Ambron (2003), the mRNA presence does not necessarily mean the presence of the protein product because there are different mechanisms of gene expression and gene regulation, which can be used according to the need of the cell.

Another aspect that must be considered is complex genetic control system of physiological quality in soybean seeds due to involvement of many genes. In this situation, studies focused on the expression of these genes by transcripts means can be limited, since the major isoenzymes in the deterioration processes, respiration and germination are encoded by different genes. Studying a major gene effect require more complex studies, not always feasible for the selection of them, due to the larger number of genes, and minor effects, associated to the physiological quality characteristic.

Thus, when evaluating the isoenzyme expression by electrophoresis technique, several enzymes encoded by different genes having affinity for the same substrate; can be expressed. Thus, the transcripts selected; in this type of study, may be more restricted at the detremination stage of proteomic analysis. An example is MDH, which is expressed in the cytoplasm, mitochondria and peroxisomes, and is encoded by different genes.

In addition to the above mentioned aspects characteristics linked to the soybean seed tegument, such as lignin, can also influence in the physiological quality of seeds. Based on the results observed in this study, it was noted that the expression of genes related to the physiological quality of seeds is more important in situations in which there is some stress condition. In this research it was possible with a harvest delay of 15 days after the $\mathrm{R} 8$ stage. It is further understood that the selection of enzymes related to the characteristic of seed physiological quality encoded by few genes are important in studies of this kind. 


\section{Conclusions}

There is higher enzymes expression involved in the respiration process, for alcohol dehydrogenase (ADH), malate dehydrogenase (MDH) and phosphoglucoisomerase (PGI) in soybean seeds with high physiological quality.

The proteomic and transcriptomic profiles related to genes involved in free radicals removing systems in soybeans seeds vary among cultivars and the season of seed harvest.

\section{Acknowledgements}

The authors thank the Foundation for Research Support of the State of Minas Gerais (FAPEMIG), the Coordination for the Improvement of Higher Education Personnel (CAPES), and The National Council for Scientific and Technological Development (CNPq), for financial support and scholarships.

\section{References}

Bowler, C., Montagu, M. V., \& Inzé, D. (1992). Superoxide dismutase and stress tolerance. Annual Review of Plant Physiology and Plant Molecular Biology, Palo Alto, 43, 83-116. https://doi.org/10.1146/annurev. pp.43.060192.000503

Braccini, A. L., Múcio, S. R., Maria, do C. L. B., Carlos, A. S., \& Ivo, de S. M. (2000). Germinação e sanidade de sementes de soja (Glycine $\max (\mathrm{L}$.) Merrill) colhidas em diferentes épocas. Acta Scientiarum, 22(4), 1017-1022.

MAPA (Ministério da Agricultura, Pecuária e Abastecimento). (2009). Regras para análise de sementes (p. 395). Brasília, Brazil.

Buchanan, B. B., Gruissem, W., \& Jones, R. L. (2005). Biochemistry \& molecular biology of plants (p. 1367). Rockville: American Society of Plant Physiologists.

Carrington, J. C., \& Ambros, V. (2003). Role of MicroRNAs in plant and animal development. Science, 301(5631), 336-338. https://doi.org/10.1126/science.1085242

Carvalho, E. R. (2013). Manganês via foliar em soja convencional e transgênica RR: efeitos na qualidade de sementes, atividade enzimática, lignina e produtividade (p. 314, Tese (Doutorado em Fitotecnia), Universidade Federal de Lavras, Lavras, MG).

Castro, M. B. (2011). Avaliação da qualidade fisiológica de sementes de milho por meio da atividade respiratória (Dissertação (Mestrado em Fitotecnia), Universidade Federal de Lavras, Lavras, MG).

Fehr, W. R., \& Caviness, C. E. (1977). Stage of soybean development (p. 11). Ames: Iowa State University.

França Neto, J. B., Krzyzanowski, F. C., Pádua, G. P. de, Costa, N. P. da, \& Henning, A. A. (2010). Tecnologia da produção de semente de soja de alta qualidade. Informativo ABRATES, 20(3), 26-32.

Gris, C. F., Von Pinho, E. V. de R., Andrade, T., Baldoni, A., \& Carvalho, M. L. de M. (2010). Qualidade fisiológica e teor de lignina no tegumento de sementes de soja convencional e transgênica RR submetidas a diferentes épocas de colheita. Ciência e Agrotecnologia, 34(2), 374-381. https://doi.org/10.1590/S1413-705 42010000200015

Jeng, T. L., \& Sung, J. M. (1994). Hydration effect on lipid peroxidation and peroxide scaveging enzymes activity of artificially age penault seed. Seed Science and Technology, 22(3), 531-539. https://doi.org/10.1111/j.13993054.1994.tb00658.x

Kuhn, H., Kleter, G. A., Noteborn, H. P., \& Kok, E. J. (2001). Assessment of the food safety issues related to genetically modified foods. The Plant Journal, 27(6), 503-528. https://doi.org/10.1046/j.1365-313X. 2001.01119.x

Lehninger, A. L. (2006). Princípios de bioquímica (4th ed., p. 1130). São Paulo: Sarvier.

Lin, C. F., Jiang, L. Z., Zhang, X. N., Qian, X. Y., Liang, Z. S., \& Yang, J. S. (2003). Cloning and prokaryotic expression of a cDNA encoding a putative mitochondrial malate dehydrogenase in Oryza sativa. DNA Sequence, 14(1), 75-77. https://doi.org/10.1080/104251703100 0062800

Martins, C. A. O., Carlos, S. S., Maria, G. De A. O., Inês, C. J., Maurílio, A. M., Múcio, S. R., \& Valterley, S. R. (2000). Atividade da isocitrato-liase durante a germinação de sementes de soja. Revista Brasileira de Sementes, 22(1), 42-46. https://doi.org/10.17801/0101-3122/rbs.v22n1p42-46 
Menezes, M., Von Pinho, É. V. de R., José, S. C. B. R., Baldoni, A., \& Mendes, F. F. (2009). Aspectos químicos e estruturais da qualidade fisiológica de sementes de soja. Pesquisa Agropecuária Brasileira, 44(12), 1716-1723. https://doi.org/10.1590/S0100-204X2009001200022

Ometo, J. C. (1981). Bioclimatologia vegetal (p. 525). São Paulo: Agronômica Ceres.

Polizel, A. M., Medri, M. E., Nakashima, K., Yamanaka, N., Farias, J. R., de Oliveira, M. C., ... Nepomuceno, A. L. (2011). Molecular, anatomical and physiological properties of a genetically modified soybean line transformed with $r d 29 A$ AtDREB1A for the improvement of drought tolerance. Genetics and Molecular Research, 10(4), 3641-3656. https://doi.org/10.4238/2011.October.21.4

Ribeiro, A. C., Guimarães, P. T. G., \& Vicente, V. H. A. (1999). Recomendações para o uso de corretivos e fertilizantes em Minas Gerais: $5^{a}$ aproximação (p. 359). Lavras: UFLA.

Santos, H. O., Von Pinho E. V., Von Pinho, I. V., Dutra, S. M., Andrade, T., \& Guimarães, R. M. (2015). Physiological quality and gene expression during the development of habanero pepper (Capsicum chinense Jacquin) seeds. Genetics and Molecular Research, 14, 5085-5098. https://doi.org/ 10.4238/2015.May.12.11

Santos, H. O., Dutra, S. M. F., Pereira, R. W., Pires, R. M. De O., Von Pinho, É. V. De R., Rosa S. D. V. F. Da, \& Carvalho, M. L. M. De. (2016). Physiological quality of habanero pepper (Capisicum chinense) seeds based on development and drying process. African Journal of Agricultural Research, 11, 1102-1109. https://doi.org/ 10.5897/AJAR2015.10462

Stolf-Moreira, R., Medri, M. E., Neumaier, N., Lemos, N. G., Pimenta, J. A., Tobita, S., ... Nepomuceno, A. L. (2010). Soybean physiology and gene expression during drought. Genetics and Molecular Research, 9(4), 1946-1956. https://doi.org/10.4238/vol9-4gmr851

Taiz, L., \& Zeiger, E. (2004). Fisiologia vegetal (3rd ed., p. 719). Porto Alegre: Artmed.

Vieira, R. D., \& Carvalho, N. M. (1994). Testes de vigor em sementes (p. 164). Jaboticabal: FUNEP.

Vieira, R. D., \& Krzyzanowski, F. C. (1999). Teste de condutividade elétrica. In F. C. Krzyanowski, R. D. Vieira, \& J. B. França-Neto (Eds.), Vigor de sementes: conceitos e testes (pp. 1-26). Londrina: ABRATES.

Weeden, N. F., \& Wendel, J. F. (1990). Genetics of plant isozymes. In D. E. Soltis, \& P. S. Soltis (Eds.), Isozymes in plant biology (pp. 46-72). London: Chapman and Hall.

Zhang, J., \& Kirkham, M. B. (1994). Drought-stress-induced changes in activities of superoxide dismutase, catalase, and peroxidase in wheat species. Plant Cell and Physiology, 35(5), 785-791. https://doi.org/10.1093/ oxfordjournals.pcp.a078658

\section{Copyrights}

Copyright for this article is retained by the author(s), with first publication rights granted to the journal.

This is an open-access article distributed under the terms and conditions of the Creative Commons Attribution license (http://creativecommons.org/licenses/by/4.0/). 